\title{
Open Issues at the Conclusion of Privatization (Corporate Ownership Restructuring) in Slovenia
}

\author{
Jure Kovac ${ }^{*}$
}

Numerous restructuring processes currently evolving in our country at various levels, are mutually intersecting and sometimes even dependent of each other. Individual processes may be classified according to their importance and the impact they have upon the global transformation of our society.

Restructuring of the economy is positively one of the most complex processes, bound to induce profound changes and distinguishing effects upon our future. Designation of such economic structure that will be able to successfully cope with competition and integrate into global economic trends is, and probably will be a multiple year process which can not be carried out without major difficulties and turmoils.

The entire process of economic restructuring has been developing at various levels and specific areas of interest, including ownership restructuring, corporate legal status and international economic integration. The source of modifications in the national economy is definitely the construction of new social system, and the ownership restructuring, popularly called privatization.

The restructuring of ownership takes a central position in the modification of economic structure. Fundamental legal grounds for the ownership restructuring are various Acts, passed by the legislation: Corporate Ownership Restructuring Act passed in 1992, has defined the methods and the configuration of the ownership restructuring (excluding public enterprises, insurance companies and banks), Commercial Corporations Act passed in 1993, has determined the legal and statutory structure, and Employee Participation Act passed in 1993, setting the model of associate participation in management (this Act relies heavily upon the German model of employee participation).

Today the corporate ownership restructuring process in Slovenia (with the exception of banks, insurance companies and public enterprises) has approached its final phase. It is safe to estimate that around $80 \%$ of the total number of corporations participating in the ownership restructuring process had acquired new and recognized owners. The draft of the new Bill, regarding the completion of the ownership restructuring, has already been lodged into the Parliament

\footnotetext{
* Jure Kovac, University of Maribor, Faculty of Organizational Sciences, Kranj, Slovenija
} 
procedure. This Bill is expected to rectify certain irregularities and misinterpretations, detected during the restructuring process.

Early analyses of the ownership restructuring process results have opened several issues of key importance to the further integration of the Slovenian economy into the global economic tendencies, such as the question whether the privatization process could contribute to better competitive position of our enterprises at the international market.

Prior further elaboration it is necessary to hover briefly upon the methods applied in the process of privatization in Slovenia. The formula included the combination of charge-free distribution, and deferred payment acquisition of property. According to the Corporate Ownership Restructuring Act, 40\% of corporate property was intended to be distributed among the employees and other Slovenian citizens, $40 \%$ was intended for paid acquisition, and the remaining $20 \%$ should have been allocated for specific purposes in equal shares to the National Retirement Fund and for the State Compensation Agency requirements in the denationalization proceedings.

Each citizen of the Republic of Slovenia has in the year 1993 been allocated a share certificate, the value of which had been determined by the person's age. Each person could therefore exchange the value of the certificate for a property share of a chosen company, or invest its value in one of numerous investment funds (who also took part in the privatization process). Companies had a choice of models, offered by standing legislation, to follow for their ownership restructuring. The selection of any particular model has been completely left to the discretion of individual companies. There were of course some limitations, but mostly regarding the size and the value of a company and consequently the choice of ownership models. Companies with strong financial and capital base for example, experienced great difficulties to gather any significant ownership share with only the value of certificates gathered from employees, their retired workforce and relatives. On the other hand, companies with powerful labor background, as well as small size companies, managed to acquire the controlling share of ownership with internal buyout, based upon certificates of their own actual and former employees and their relatives.

This method consequently resulted in two prevailing company ownership configurations in Slovenia. One consists of companies with prevailing internal ownership structure (including actual and former associates and their close family members), and the other with prevailing number of external owners (including representatives of various funds, business partners, and others). The results of the first analyses regarding the financial results of companies with dispersed capital ownership, carried out by CEEPN (Central \& Eastern European Privatization Network) (Simoniti et al., 1998) display some interesting facts. 
In this particular analysis the CEEPN experts, working in collaboration with outside fellow researchers, wanted to check the following hypotheses, that have recently gained importance within the professional world:

companies with prevailing exterior owners indicate the trend of exhausting the company resources by the pressure for dividend payouts;

companies with prevailing interior owners indicate the distribution in favor of labor element, equally exhausting the ompany resources and reducing the chances of internal financing of investments;

The corpus consisted of 933 restructured companies, of which 787 with prevailing internal ownership and 346 with external ownership. The period comprised years 1994, 1995 and 1996. The above stated corpus represents a major corporate share in the economic structure of Slovenia, since the cited 933 companies handled $32,2 \%$ of assets and owned $37,1 \%$ of capital of all Slovenian enterprises.

The results of the analysis indicated the following features: the volume of profit from operations and of net profit clearly indicate that companies with prevailing exterior ownership are more successful than those with internal ownership. Companies with employees holding the controlling share of ownership indicate trouble in handling expenditures. Whilst in the monitored period the companies with controlling ownership share held by exterior owners reported net profits in the annual amount of round SIT 8 billion (DEM 85 million), the companies with internal owners reported clean loss in the years 1994 and 1995, and a positive zero standing in the year 1996.

Some other financial indicators also display more successful economic performance of companies owned by major exterior shareholders. Those companies indicate:

- higher amount of added value per employee;

reduced indebtedness and increased amount of investments into fixed assets;

increase of employment and sales revenue growth.

Companies with prevailing employee ownership are in the process of passive restructuring. They display the increased borrowing trend, devestments, etc. (Simoniti, 1998).

Reviewing these data, a question comes forward: is internal ownership impeding the process of active restructuring of companies and consequently their integration into the global economic activities?

Workforce in Slovenia has got decades of experience in the area of participation in management, from the times of associated labor and self-governing. However, major number of serious empirical analyses carried out in the self-governing socialist era, indicated that the power of decisions, notwithstanding the 
institutionalized model of workers' participation in the administration, laid in the hands of management. Whilst employees may have had formal right of governing the company, the actual decision-making never left the hands of management. It is therefore difficult to expect that experience, dating from the recent self-governing age, may be successfully applied in the new circumstances with the internal ownership model.

It is our estimate that the leap into the new environment has been experienced by most labor force as a major modification and the introduction of related novelties that most of them still haven't actually realized as yet. Globalization and constant struggle for better competitive position both represent notions that most employees have yet started to recognize. In this moment, companies with mostly internal owners carry out the process of adjusting to new market circumstances rather slow, or maintain the status quo. Managers in such companies have also adjusted to the actual situation and do not wish to exert any unpopular measures.

But the described situation may be detrimental for particular companies. Some managers in these companies have realized the solemnity of the situation and have released comprehensive reorganization projects. In most cases the restructuring process is bound to bring negative consequences for the workforce (redundancies, wage reduction, etc.). Employees react negatively to such radical approaches. In Slovenia we have witnessed first management substitutions in companies with prevailing internal ownership structure, where the managers intended to remodel the company and get ready for the incoming competition (integration in EU).

There is no doubt that the actual ownership structure will further modify in the future. We may expect gradual concentration of ownership structure, which is quite dispersed at the moment. Trends in this area support this statement. Such big number of companies with prevailing internal ownership structure in Slovenia will not be able to remain for long in the future. The restructuring process requires the modification of ownership structure (entry of foreign strategic partners, or bankruptcy). The existing situation in the area of internal ownership is a very rich experimental space to study the scope of employee participation in the management of a company.

Managerial styles in companies with different ownership structure would be quite an interesting area of study. There is no warranty that managers in companies with prevailing internal ownership structure exercise more participative method of management compared to others. Findings based on indirect data and arising from empirical research in the area of communication (Kavčič, 1996) indicate major communication problems in the relationship between the managers and their associate employees. Equally, there is a gap regarding the availability of information employees may obtain about the 
situation in the company at a given moment. This is frequently the reason for strikes and other forms of protest.

In the following years it is safe to forecast a rather dynamic activity in the area of changing existing company ownership structures in Slovenia. It is therefore somewhat premature to try evaluating the prosperity of any particular form of company ownership structure based on existing experience.

\section{References:}

Simoniti Marko(et al.) (1998):Certain features of operations in companies with internal and external owners, CEEPN, Ljubljana;

Kavčič Bogdan (1996): Analysis of carrying out the Employee Participation Act, ITEO, Ljubljana; 